УДК 791.43-92:7.08(477)"201”

Москаленко-Висоцька Олена Миколаївна доиент кафедри кіно-телемистеитвва, Київський національний університет культури і мистеитв, Київ, Україна film_editor@ukr.net

\title{
ЖАНРОВИЙ СПЕКТР ДОКУМЕНТАЛЬНИХ ФІЛЬМІВ СТУДІЇ «УКРКІНОХРОНІКА» ПОЧАТКУ ХХІ СТОЛІТТЯ
}

Мета дослідження. У роботі подається визначення палітри жанрового спектру документальних кінострічок українських кінодокументалістів періоду початку 2001-го р. Об'єктом наукового дослідження виступає сукупність фільмотворчих процесів, що мали місце у творчо-виробничій лабораторії Української студії хронікально-документальних фільмів. Мета дослідження. На основі аналізу кількох фільмів студії «Укркінохроніка» окреслити жанрові та тематичні засади специфіки документального кіно зазначеного періоду. Методологію дослідження складають емпіричний та теоретичний аналізи антологіону фільмів, створених на державному підприємстві «Укркінохроніка». Розгляд екранних творів, а саме - кількох короткометражних докуменальних фільмів, проводиться на основі аналізу взаємовідношення авторів та їх творчих практик з матеріалом життя, а також методом порівняння художніх стилів та авторських концепцій, що умотивовуються певними жанрами. Предметом дослідження стали короткометражні документальні фільми українських режисерів Валентина Васяновича та Олеся Саніна. Висновки. На основі результатів дослідження документальних фільмів ДП «Українська студія хронікально-документальних фільмів» зроблено послідовне обгрунтування різновиду жанрово-тематичних особливостей фільмів, створених на початку 2001-го р. У роботі усебічно визначено жанровий спектр фільмів, що створювались у перехідний для країни період соціально-економічних зрушень. Досліджено процес створення контенту неігрових фільмів через зазначення творчих методів кінорежисерів нового покоління. У роботі здійснено аналіз різнопланового використання жанрів як прояву авторського відношення до екранного матеріалу. Представлена наукова робота $\epsilon$ першою у низці робіт автора, присвячених дослідженню жанрово-тематичного спектра фільмів студії «Укркінохроника» періоду від 2001 по 2017 рр. У наступних роботах планується продовження тематично-жанрового дослідження, в якому вперше буде узагальнено досвід 
кінематографістів ДП «Українська студія хронікально-документальних фільмів» в контексті соціальних перетворень українського суспільства на початку нового тисячоліття.

Ключові слова: жанри, документальні фільми, авторське рішення, екранний образ, режисер фільму, звукова драматургія, фільм-портрет, пастораль, драма, арт-хаус.

Москаленко-Высоцкая Елена Николаевна, дочент кафедри кинотелеискусства, Киевский национальный университет культуры и искусств, Киев, Украина

Жанровый спектр документальных фильмов студии «Укркинохроника» начала XXI века

Цель исследования. В работе подается определение палитры жанрового спектра документальных кинолент украинских кинодокументалистов в начале 2001 года. Объектом научного исследования выступает совокупность фильмопроизводящих процессов, имевших место в творческо-производственной лаборатории Украинской студии хроникально-документальных фильмов. Цель исследования. На основе анализа нескольких фильмов студии «Укркинохроника» определить жанровые и тематические основы специфики документального кино предлагаемого периода. Методологию исследования составляют эмпирический и теоретический анализы антологиона фильмов, созданных на Государственном предприятии «Укркинохроника». Рассмотрение экранных произведений, а именно - короткометражных докуменальних фильмов, проводится на основе анализа взаимоотношения авторов и их творческих практик с материалом жизни, а также методом сравнения художественных стилей и авторских концепций, вмотивированных определенными жанрами. Предметом исследования стали короткометражные документальные фильмы украинских режиссеров Валентина Васяновича и Олеся Санина. Выводы. На основе результатов исследования нескольких документальных фильмов ГП «Украинская студия хроникально-документальных фильмов» сделано последовательное обоснование разновидности жанрово-тематических особенностей фильмов, созданных в начале 2001 г. В работе всесторонне определен жанровый спектр фильмов, которые создавались в переходный для страны период социально-экономических сдвигов. Исследован процесс создания контента неигровых фильмов через призму творческих методов кинорежиссеров нового поколения. В работе проведен анализ разнопланового использования жанров как проявления авторского отношения к экранному материалу. Представленная научная работа является первой в ряду работ автора, посвященных исследованию жанрово- 
тематического спектра фильмов студии «Укркинохроника» периода с 2001 по 2017 гг. В следующих работах планируется продолжение тематически-жанрового исследования, в котором впервые будет обобщен опыт кинематографистов ГП «Украинская студия хроникально-документальных фильмов» в контексте социальных преобразований украинского общества в начале нового тысячелетия.

Ключевые слова: жанры, документальные фильмы, авторское решение, экранный образ, режиссер фильма, звуковая драматургия, фильм-портрет, пастораль, драма, арт-хаус.

Moskalenko-Vysotska Olena, Associate Professor of the Department of Cinema and Art, Kyiv National University of Culture and Arts, Kyiv, Ukraine

The genre spectrum of documentary films of the «Ukrkinokhronika» studio at the beginning of the $21^{\text {st }}$ century

The purpose of the study is to define the palette of the genre spectrum of documentary films by the Ukrainian documentary filmmakers of the beginning of the year 2001. The target of the research is a set of film-producing processes that took place in the creative and production laboratory of the Ukrainian studio of chronicle and documentary films. The purpose of this study is to determine the genre and thematic fundamentals of the specifics of documentary films of the period under research, based on the analysis of several films produced by the «Ukrkinokhronika» studio. The research methodology consisted in the empirical and theoretical analysis of the anthology of the films created at the state enterprise «Ukrkinokhronika». The review of screen works, namely several short documentary films, was conducted on the basis of the analysis of the relationship of the authors and their creative practices with the material of life, as well as by means of comparing artistic styles and authorial concepts, motivated by certain genres. The subject of the research was represented by short documentary films by Ukrainian directors Valentyn Vasianovych and Oles Sanin. Conclusions. Based on the results of the research into the documentary films by the state enterprise «Ukrainian Studio of Chronicle and Documentary Films», the consistent substantiation of a variety of genre and thematic features of films created during the year 2001 was made. The work thoroughly defined the genre spectrum of films that were created in the transition period of the country's socio-economic breakthrough. The process of creating content of nonfeature films through the prism of the creative methods used by the filmmakers of the new generation was explored. The work analyzed the diverse use of genres as a manifestation of the author's attitude to the screen material. This scientific work is the first in a number of author's works devoted to the study of the genre and thematic 
spectrum of the films by the «Ukrkinokhronika» studio from 2001 to 2017. In the following works, it is planned to continue the thematic-genre research, in which the experience of cinematographers of the state enterprise «Ukrainian Studio of Chronicle and Documentary Films» will be generalized for the first time in the context of social transformations of the Ukrainian society at the beginning of the new millennium.

Key words: genres, documentary films, author's concept, screen image, film director, sound drama, film-portrait, pastoral, drama, arthouse.

Вступ. Переступивши поріг Міленіуму, Україна, продовжує створювати документальні фільми. Хоча і в скрутній ситуації щодо невеликої фінансової дотації, держава, все ж таки, підтримує їх випуск. Вітчизняні кінодокументалісти наполегливо шукають свою драматургію, освоюючи нові художні принципи, оновлюючи попередні та відкриваючи нові для себе жанри міксованих форм.

Предмет цієї роботи - дослідження тематичних та жанрових напрямків документального кінематографу на прикладі фільмів Державного підприємства «Українська студія хронікально-документальних фільмів», створених на початку XXI ст.

Розглянемо перші твори кінодокументалістики періоду 2001 р., щоб зробити деякі висновки відносно того, що опинилося у центрі уваги українських режисерів, познайомитися 3 персоналіями авторських фільмів та спробувати визначити державні пріоритети у підтримці документального кіномистецтва.

Мета дослідження. На основі аналізу фільмів студії «Укркінохроніка» окреслити жанрові та тематичні засади специфіки документального кіно зазначеного періоду. Розгляд екранних творів, а саме - кількох короткометражних докуменальних фільмів, проводитиметься на основі аналізу взаємовідношення авторів та їх творчих практик з матеріалом життя, а також методом порівняння художніх стилів та авторських концепцій, що умотивовуються певними жанрами.

В українському кінознавстві теми жанрів вітчизняних фільмів та телепередач торкалися багато мистецтвознавців та творців фільмів, зокрема, Г. О. Десятник, О. С. Мусієнко, І. Б. Зубавіна, Л. І. Брюховецька, С. Д. Безклубенко, М. І. Мазур, М. І. Недопитанський, Б. В. Потятник, Л. М. Кульчинська, Д. М. Колос, Р. Н. Ширман та ін. У своїх роботах, аналізуючи художню своєрідність творів, автори розглядали жанрові особливості ігрових та документальних фільмів та телепроектів, але не торкались питань тематично-жанрової систематизації документальних фільмів, створених документалістами студії «Укркінохроніка», на початку XXI ст. 
Оригінальність даної роботи полягає в тому, що вперше в українській кінознавчій практиці представляється дослідження жанрово-тематичного стану контенту, виробленого єдиною в Україні державною студією документальних фільмів («Укркінохроніка») в один 3 найскладніших періодів вітчизняного кінематографу $2001 \mathrm{p}$.

Ціль, яку ставить перед собою автор даної роботи - це доведення, що і в умовах складних соціальних зрушень, жорсткої державної економії, документальний кінематограф не тільки не зупинився, але й продемонстрував неабиякий різноплановий спектр жанрів українського кіно.

Робота розрахована на використання систематизованого фактажного матеріалу серед науковців-мистецтвознавців та студентів творчих вузів.

Нове тисячоліття досить стримано відкрило обійми представникам української кіногалузі. Якщо за інерцією у 90-ті рр. кіностудії ще випускали до десятка фільмів у рік кожна, то, починаючи від 1996 р., їх кількість зменшувалася, і в останні два роки XX ст. галузь кіновиробництва в Україні майже зупинилася.

Шукаючи вихід, держава намагалася знайти нові правила функціонування галузі кіно, приставши до новітньої для нашої країни (після 1917 р.) продюсерської системи, яка передбачає пошуки інвесторських фінансів і лише часткову державну підтримку.

Перед вітчизняними кінематографістами, які за радянської системи звикли до суцільного державного фінансування, постало багато питань - творча не завантаженість, відсутність фінансування, зміни у системі відбору матеріалу, пошуки тем в умовах новітньої історії країни, тощо.

Та в природі нічого не стоїть на місці. Хоча й зі скрипом, з хрускотом усіляких нарікань, епістолярними бійками та перманентним обопільним невдоволенням митців та керівництва галуззю, кінематографічне колесо, все ж таки, почало розкручуватись і набирати обертів.

У складному перехідному періоді творці сублімували у своїх творах образи через рефлексії. За словами українського мистецтвознавця Олександра Соловйова «...гіперрефлексія сучасного українського мистецтва $є$ його загальною рисою» [8, с. 48], тому не обійшла ця тенденція і кіномистецтво.

Перш за все, звернемо увагу, що саме на початку нового тисячоліття лави кінодокументалістів поповнилися молодими режисерами, випускниками кінофакультету Київського державного інституту театрального мистецтва імені I. К. Карпенка-Карого. Так, зокрема, на студію «Укркінохроніка» прийшли: Валентин та Максим Васяновичі, Олесь Санін, Максим Сурков, Марина Кондратьєва. Їх авторські документальні короткометражки принесли студії свіжу хвилю креативу на екрані та низку нагород міжнародних кінофестивалів. 
Першим з них стартував фільм «Старі люди» (оператор Валентин Васянович), створений у 2001 р. братами Валентином та Максимом Васяновичами. Це колективний фільм-портрет жителів села, з якого йде родовід авторів. Половину села там Васяновичі. Зрозуміло, що брати, хоч і мешканці міста, але добре знають село своїх предків і характери його мешканців. Це допомогло дуже реально 3 теплотою і гумором представити їх екранний портрет у своєму фільмі-дебюті.

Упродовж роботи над фільмом їх творчі задуми зазнавали змін, і якщо на початку молоді автори планували розкрити тему в жанрі легенди, то, заглибившись у матеріал, зрозуміли, що жанрове рішення таїться в іншому ключі.

Спочатку вони з братом написали сценарій на основі 5-ти легенд, які розповідала їм бабця із села Мелені, та приїхавши на зйомки, брати відмовились від написаного сценарію і почали творчі пошуки його нового змісту і тексту.

Звертаючись до означення видозміни сценарію, про які підсумовує у своїй науковій роботі «Кіносценарій як квазідраматургічний жанр» мистецтвознавець Н. В. Нікоряк, «...становлення сценарного тексту як автентичного жанрововидового утворення слід спостерігати у перспективі динамічної жанрової метаморфності усієї драматургічної історії, а також у зв'язку з автономізацією саме літературного первня означеної форми» [4, с. 113], можна констатувати, що молоді режисери припустили кардинальні зміни у своєму сценарії, змінивши не тільки драматургічний хід, але й стиль та жанр майбутньої кінооповіді.

Як розповідав В. Васянович публіцисту Олексію Радинському: «Ми почали знімати все, як воно справді є. Зрозуміли, що кіно робити треба синхронно. Наша бабця працює листоношею, і на цьому ми побудували фільм - їздить вона по селу, зустрічає людей, усе бачить, усе чує. Я взагалі за синхронне кіно. Воно заворожує. Не люблю закадрових авторських текстів:

«I ось такий-то поміркував і вирішив...». Під час синхрону персонаж оживає, у звичайнісінькій людині стільки неочікуваних нюансів відкривається!» [7, c. 50].

Тоді для авторів фільму вимальовувався реальний обрис колективного портрету жителів одного з житомирських сіл. Вибравши за основу жанр фільмупортрету, автори шукали ще й додатковий жанровий нюанс, адже кожен режисер вирішує свій фільм у певному жанрі в залежності від особистого погляду на матеріал, над яким він працює.

Відомий кінорежисер, заслужений діяч мистецтв України, професор Р. Н. Ширман у своїй книзі «Алхімія режисури. Майстер-клас» окреслив певну особливість жанру: «Вибір героїв і точка зору режисера зумовлюють жанр 
майбутнього фільму. Саме визначення «фільм-портрет» мало що говорить. Портрет може бути панегіриком, мелодрамою, трагедією, трагікомедією... Але жанр твору не 3'являється сам по собі. Режисер, познайомившись 3 героєм, визначивши, про що саме і навіщо він буде знімати фільм, всі епізоди вже буде будувати певним чином, під необхідним кутом зору» [10, с. 249-250].

Коли виробництво фільму «Старі люди» завершилося, його стильова структура була цікавою, складною і неоднорідною, в ній проступали риси і комедійного, і драматичного, i, навіть, пасторального жанру.

Якщо зважити, що за визначенням Універсального словника-енциклопедії «Пастораль - це драматичний твір про щасливе й безтурботне життя пастухів» [9, с. 1031], то стилістично кінострічка «Старі люди» вирішена авторами саме у жанрі трагікомічної анти-пасторалі. Жителі одного 3 житомирських сіл з гумором розповідають про кумедні і щасливі моменти свого життя, але за всім цим проступає прихований драматизм, який поглиблює і ускладнює простий жанр пасторалі.

Породжена ще у добу Раннього Ренесансу, пастораль акцентувала на зіставленні розбещеному місту етично чистого села, інтересу до природи, світу відчуттів і побуту простих людей. У фільмі «Старі люди» саме пастораль найбільшою мірою відповідає цілісному і гармонійному ренесансному світовідчуттю простих сільських бабусь та дідусів які, пройшовши непросте життя, зберегли чисте і радісне відношення до світу і всього, що їх оточує.

Кінострічка «Старі люди» представила значний творчий потенціал режисера-оператора Валентина Васяновича, і це природньо, адже він мав підготовку у таких творчих майстернях українських кінематографістів, як Олексія Прокопенка та Олександра Коваля (1990-1995 рр., 1995-2000 рр., Україна), а через кілька років ще й успішно закінчив Школу режисерської майстерності Анджея Вайди (2006-2007 рр., Польща).

Невдовзі після виходу, фільм «Старі люди» отримав Диплом фестивалю документальних фільмів «Кінолітопис» (Україна, 2002 р.), другу премію на Міжнародному кінофестивалі «Золотий Витязь», (Росія, 2002 р.) та перший приз за найкращий документальний фільм Міжнародного фестивалю в Баку (Азербайджан, 2003 р.).

Зовсім у іншому ключі, але не менш цікавому міксі жанрових перехресть, створив свій короткометражний документальний фільм «Різдво, або як гуцули кінця світу чекали» молодий режисер-документаліст Олесь Санін - учень кінорежисера Леоніда Осики. Його старт і подальші екранні роботи принесли режисерові заслужену славу і почесні звання, нині Олесь Санін вже заслужений артист України, лауреат Державної премії України імені Олександра Довженка, 
володар «Срібної медалі» Академії мистецтв України та «Срібної медалі» імені братів Люм'єрів, автор низки документальних стрічок та художніх фільмів «Мамай» і «Поводир».

Документальну кінострічку «Різдво, або як гуцули кінця світу чекали», Олесь Санін відзняв у 2001 році саме на «Укркінохроніці», невдовзі після свого вдалого дебюту на цій студії документальною стрічкою «Гріх. Камінний хрест» (1999р.), присвяченої історії створення шедевра Леоніда Осики - кінофільму «Камінний хрест».

Автор-режисер працював над створенням картини «Різдво...» в глибинці українських Карпат, де живуть гуцули. Їх прадавній світ і традиції, що не мали змін вже понад два тисячоліття, стали основою документального фільму.

Будь-яка драматична дія все одно базується на якійсь міфологемі. Тлумачення міфологічних образів та сюжетів, які мали широке культове розповсюдження в культурі гуцульського народу - основний стрижень оповіді у фільмі Олеся Саніна.

«Різдво» - авторська спроба Саніна розкрити таємничий світ гуцулів. Гуцульщина для режисера - місце, де звичні часові координати майже повністю зітерто. В цьому - феномен гуцульського світогляду, - зазначає у своїй статті «Весна кінодокументалістики» Олексій Радинський. - ...У фільмі Саніна також немає жодних часових ознак...3 «Різдва» видалено все, що могло б повернути глядача до року від Різдва Христового дві тисячі першого, в якому де-факто відбуваються події фільму, - відзначення релігійних свят. Одні й ті самі ритуали виконуються на Гуцульщині протягом століть, і хтозна, чи колись настануть зміни. Тож закономірно, що гуцульські хрести, предмети культу в фільмі мають вигляд химерний, язичницький. Час не зупинився, його просто нема» [6, с. 48].

Стилістика фільму О. Саніна переймає дух старої кінохроніки - чорнобіле кіно, написи - стилізовані титри - ніби з епохи «Великого німого». Камера відомого кінооператора Сергія Михальчука створює етнічні картини образів напів-містичного життя жителів українських Карпат, які живуть поза часом, у просторі своїх традицій, вірувань і міфів.

Як висловився у своїй книжці «Теорія смислів світового кіно» український кінорежисер Василь Ілляшенко - «Кінематограф світу пучком променів кінооператора має пояснити світу свою філософію» [2, с. 5].

Фільму О. Саніна, безперечно, властиві тяжіння до філософічності й підтексту. Його поліфонічність стилю має глибинні пошуки думки й форми філософії існування, в екзистенціальності якої домінантою $є$ певна трагічність. Категорія «трагічного» має багатовікову історію. Першим теоретиком трагічного був Арістотель. Він вважав, що трагічне має об'єктивний характер, 
у його основі - перехід від щастя до нещастя. Людина зазнає нещастя тому, що вступає у конфлікт з долею. Саме ці інфернальні питання людини і фатуму, людського життя і природи, є центральними в фільмі режисера О. Саніна, виражені в драматичному жанрі.

Відомо, що на противагу фільмів інших жанрів, основна увага в драмі акцентується не на поворотах сюжету, спецефектах чи видовищності, а саме на переживаннях героїв. Своє авторське кіно режисер Олесь Санін вирішив у одному з різновидів цього жанру - психологічно-настроєвої драми. Настроєві домінанти у фільмі створюють полістилістичність художньої структури, що спричинює особливу психологічну напругу.

Своєрідну кіномову фільму О. Саніна «Різдво, або як гуцули кінця світу чекали» ближче до всього можна назвати авторським арт-хаусом. Складна, замішана на різних вкрапленнях інших культур, мова гуцулів несе скоріше не інформативне, а образно-характерне значення. Звукоряд заповнений не синхронами, монологами чи діалогами за кадром, а фрагментами звучання дримби, фольклорними та ритуальними співами гуцулів, молитвами, інтершумами.

Канва сюжету зводиться до коловороту подій - етнографічні обряди приготування гуцулів до Різдва, зустріч Весни, очікування Великодня, випас отар і знову приготування до Різдва. І це повторюється упродовж кількох віків, стає зрозумілим, що «гуцули не знають хронологічного числення часу, тому і не означають років числами, а називають їх після подій, які сталися на гуцульщині...кажуть: «голодного року», або «як сніги були великі» [6, с. 49].

Режисер вибудовує у своєму фільмі не просто онтологію гуцул і використовує зовсім не історичний жанр. Навпаки, у модерновій формі він препарує традиції віковічного буття, представляючи їх як циклічне духовне відродження. На думку ж відомого українського філософа С. Б. Булаго «...історичний ракурс «духовного відродження» базується не стільки на самій історії, скільки на особистісній інтерпретації історії» [1, с. 4].

Тож, особиста інтерпретація екранної історії, а також тяжіння Олеся Саніна до авангардного мистецтва, як і модерновий стиль, що прослідковується у розглянутій вище роботі Валентина Васяновича, підтверджує циклічність історичних процесів у мистецтві. Адже на зламі минулого сторіччя митці також плекали подібні мистецькі засади. Це підтверджує у своїй роботі «Нові підходи до історії українського мистецтва XX сторіччя», доктор мистецтвознавства Тетяна Кара-Васильєва, яка прослідковує подібні тенденції: «Зародження і формування авангардного мистецтва в Україні тоді відбувалося у надрах стилю модерн, у складному симбіозі європейської традиції з інспіраціями народної творчості» [3, с. 148-149]. Це твердження також підтримує мистецтво- 
знавець Марина Протас, зазначаючи, що минуле сторіччя теж починалося у мистецтві зі «звернення авангарду до народних джерел творчості, до історичної місцевої архаїки» [5, с. 11].

Підсумовуючи сказане, можна констатувати, що мистецькі пошуки молодих кінодокументалістів на зламі епох тяжіли до авангардизму в поєднанні 3 народними традиціями, а життя, яке режисери відобразили у своїх фільмах, зазнало авторської трансформації відповідно до вибраних ними жанрів.

Розпочавши дослідження контенту студії, автор дійшов висновків, що серед розглянутих кінострічок, помітно, що молоде покоління більш схильне продукувати фільми у жанровій палітрі, досить інноваційній як для вітчизняного документального кіно, на кшталт, ліричної анти-пасторалі «Старі люди», чи арт-хаусу «Різдво, або як гуцули кінця світу чекали».

Багато мистецтвознавців, режисерів, кінокритиків досліджували жанрову тему в кінематографі, серед них, зокрема, американські дослідники Рік Олтмен, Стів Ніл, російські О. Ф. Нечай, Г. В. Ватников та ін. В Україні, як вже зазначалось, аналізом жанрових практик займалися мистецтвознавці І. Зубавіна, О. Мусієнко, О. Безручко, Л. Кульчинська, В. Скуратівський, С. Безклубенко та ін.

У представленій роботі проаналізовано жанрову палітру кількох фільмів і вперше зроблена спроба дослідження творчого стилю молодих кінорежисерівдокументалістів студії у межах кореляції жанрового спектру. Це дослідження дає можливість означення перформативного аспекту жанрових категорій.

Зокрема, у роботі розпочато детальний аналіз перших фільмів студії «Укркінохроніка» 2001 р., дослідження яких буде продовжено у наступних роботах на основі антологіону документальних стрічок нового століття включно до 2017 p.

У роботі підтверджено, що звернення до певних тем і жанрів, зумовлене активним пошуком новітніх авторських рішень, що призводить до використання у одному фільмі елементів різних жанрів, збагачуючи спектральну палітру твору.

Зважаючи на те, що жанр визначається не змістом твору, а відношенням автора до теми, його кутом зору на події, котрі викладені у мистецькому творі, можна зазначити, що авторське вирішення кількох розглянутих фільмів ДП «Українська студія хронікально-документальних фільмів» за період 2001 р., досить різноманітне, що підтверджується зверненням митців у своїх фільмах до складних жанрових форм, кожна з яких має досить умовне визначення, бо містить в собі ще додаткові похідні жанри.

На підставі цього, можна стверджувати, що українські кінодокументалісти володіють досить широким спектром використання жанрових форм та тематичного діапазону. Головне полягає в тому, що підняті у фільмах теми є актуальними i, безумовно, важливими для суспільства. 


\section{Список використаних джерел}

1. Булаго С. Набег язычества / С. Булаго // Соты. - 2005. - №11. - С. 2-14.

2. Ілляшенко В. Теорія смислів світового кіно. Т. 2 / В. В. Ілляшенко. Київ : Неопалима купина, 2006. - 155 с.

3. Кара-Васильєва Т. Нові підходи до історії українського мистецтва XX сторіччя / Т. Кара-Васильєва // МІСТ: Мистецтво, історія, сучасність, теорія. 2006. - Вип. 3. - С. 145-165.

4. Нікоряк Н. Кіносценарій як квазідраматургічний жанр / Н. В. Нікоряк // Наук. зап. Харк. нац. пед. ун-ту ім. Г. С. Сковороди. Серія «Літературознавство». 2013. - Вип. 3(1). - С. 110-115.

5. Протас М. Українська скульптура XX століття / М. О. Протас. - Київ : Інтертехнологія, 2006. - 284

6. Радинський О. Весна кінодокументалістики / О. Радинський // Кінотеатр. - 2002. - №6 (44 ). - С. 48-49.

7. Радинський О. Нашому кіно живих людей не вистачає / О. Радинський // Кіно-театр. - 2002. - №6 (44). - С. 50.

8. Соловйов О. Турбулентні шлюзи / О. Соловйов // Ін-т проблем сучасного мист-ва АМУ. - Київ : Інтертехнологія, 2006. - 192 с.

9. Універсальний словник-енциклопедія / [керівник проекту: О. Коваль]. 2-ге вид., доп. - Київ ; Львів : ЛДКФ «Атлас», 2001. - 1576 с.

10. Ширман Р. Алхімія режисури. Майстер-клас / Р. Ширман. - Київ : Телерадіокур'єр, 2008. - 448 с.

\section{References}

1. Bulaho, S. (2005). The Foray of Paganism. Soty [Honeycombs], 11, pp. 2-14.

2. Illiashenko, V. (2006). Theory of Meanings of The World Cinema. Vol. 2. Kyiv : Neopalyma kupyna.

3. Kara-Vasylieva, T. (2006). New Approaches to the History of Ukrainian Art of the Twentieth Century. Mystetstvo, istoriia, suchasnist, teoriia [MIST: Art, History, Contemporaneity, Theory], 3, pp. 145-166.

4. Nikoriak, N. (2013). Screenplay as Kvazidramatic Genre. Naukovi zapysky Kharkivskoho natsionalnoho pedahohichnoho universytetu im. H. S. Skovorody Seriia : Literaturoznavstvo [Scientific Notes of Kharkiv National Pedagogical University named after H. Skovoroda, Series: Literary criticism], 3(1), pp. 110-115.

5. Protas, M. (2006). Ukrainian sculpture of the twentieth century. Kyiv: Intertekhnolohiia.

6. Radynskyi, A. (2002). The spring of documentary filmmaking. Kino-Teatr [Movie-Theater], 6(44), pp. 48-49. 
7. Radynskyi, A. (2002). Our movie lacks the living beings. Kino-Teatr [Movie-Theater], no 6(44), p. 50.

8. Soloviov, O. (2006). Turbulent Gateways. Kyiv: Intertekhnolohiia.

9. Smith A. (2001). Universal Dictionary and Encyclopedia, $2^{\text {nd }}$ ed. Kyiv; Lviv: Atlas.

10. Shyrman, R. (2008). The Alchemy of Direction. Workshop. Kyiv: Teleradiokurier.

(C) Москаленко-Висоиька О. М., 2017 